\title{
Natural Disaster in Tbilisi City (Riv. Vere Basin) in the Year 2015
}

\section{George Gaprindashvili, Merab Gaprindashvili, Emil Tsereteli}

LEPL National Environmental Agency, Department of Geology, Tbilisi, Georgia

Email: gaprindashvili.george@gmail.com

How to cite this paper: Gaprindashvili, G., Gaprindashvili, M. and Tsereteli, E. (2016) Natural Disaster in Tbilisi City (Riv. Vere Basin) in the Year 2015. International Journal of Geosciences, 7, 1074-1087. http://dx.doi.org/10.4236/ijg.2016.79082

Received: July 29, 2016

Accepted: September 13, 2016

Published: September 16, 2016

Copyright $\odot 2016$ by authors and Scientific Research Publishing Inc. This work is licensed under the Creative Commons Attribution International License (CC BY 4.0).

http://creativecommons.org/licenses/by/4.0/

\section{(c) (i) Open Access}

\begin{abstract}
During 13-14 June 2015 heavy rainfall in the Riv. Vere basin area and its tributaries caused a drastic increase in the water level and triggered/activated large-scale landslide and debrisflow events. This put the Tskneti-Samadlo and Tsnketi-Akhaldaba motorways out of order. Residential buildings and miscellaneous infrastructural facilities, buildings and structures and Tbilisi Zoo located at the low elevations in the Riv. Vere Gorge were significantly damaged or/and totally destroyed. 23 persons died during the disaster. This study presents the results on an analysis of the landslides/ debrisflows in the riv. Vere catchment and discusses main triggering factors of natural disaster, statistics for the prior period, and geodynamic situation of Akhaldaba "big" landslide developed at the Tskneti-Samadlo road section. It is given recommendations for future activities to reduce landslide/debrisflow hazard in this catchment.
\end{abstract}

\section{Keywords}

Georgia, Tbilisi, Landslide, Debrisflow, Natural Disaster

\section{Introduction}

At present, under the conditions of increased demand on constructions, the territory of Tbilisi city is being developed under the most complex geological conditions, which is frequently accompanied by widespread occurrence and activation of hazardous geological processes, such as landslide-gravitational and piping-subsiding events, floods, debris flows and flashfloods, triggered by heavy rainfal, also extreme complications of geo-ecological situation [1] [2]. 


\section{Study Area}

In Tbilisi city area and among the Riv. Vere tributaries the catchment basin of Riv. Vere and its gorge occupies a distinguished place in respect of relief peculiarities and the significance of development (Figure 1). Riv. Vere flows into Riv. Mtkvari from the right side at the Heroes Square. The total length of it is $38 \mathrm{~km}$ and the catchment basin is 194 $\mathrm{km}^{2}$. There are many important facilities and historical or cultural monuments in this catchment basin, such as Tbilisi State University buildings, TV and Circus buildings, Zoo, residential buildings and historical cultural monuments.

In hypsometric terms, the catchment basin of riv. Vere is located within three geomorphological zones: plain-terrace relief of the valley; low-mountainous piedmont; and average-mountainous mountain-gorge zones [3]. Tectonic conditions, varied sensitivity towards erosive-denudation processes of the constituent rocks, virgation of rocks folding, inclination in different directions and tectonic faults with numerous regional and local faults, -on the basic substrate of which a diversified relief is formed through erosive-denudation and gravitational process (Figure 2).

The relief of the catchment basin of Riv. Vere and the development of its main morphological element, which is the Riv. Vere Gorge, has much longer history than the other tributaries of Riv. Mtkvari within the Tbilisi area.

In the Vere Gorge, changeability of the impact of intensity and deep and lateral erosion processes is wholly dependent on the tectonic movement regime, the peculiarity of which is clearly shown by strongly expressed meanders, as the cycle of the final stage of the Gorge development. Although, in the average-height mountainous-gorge zone of the Gorge, morphologically clearly expressed steps at various hypsometric levels on its right slope is an indication that these are not sculptural-terrace steps but morphological steps formed as a result of gravitational-landslide processes emerged during the regime of lateral erosive processes of the River following the cutoff of the constituent rocks

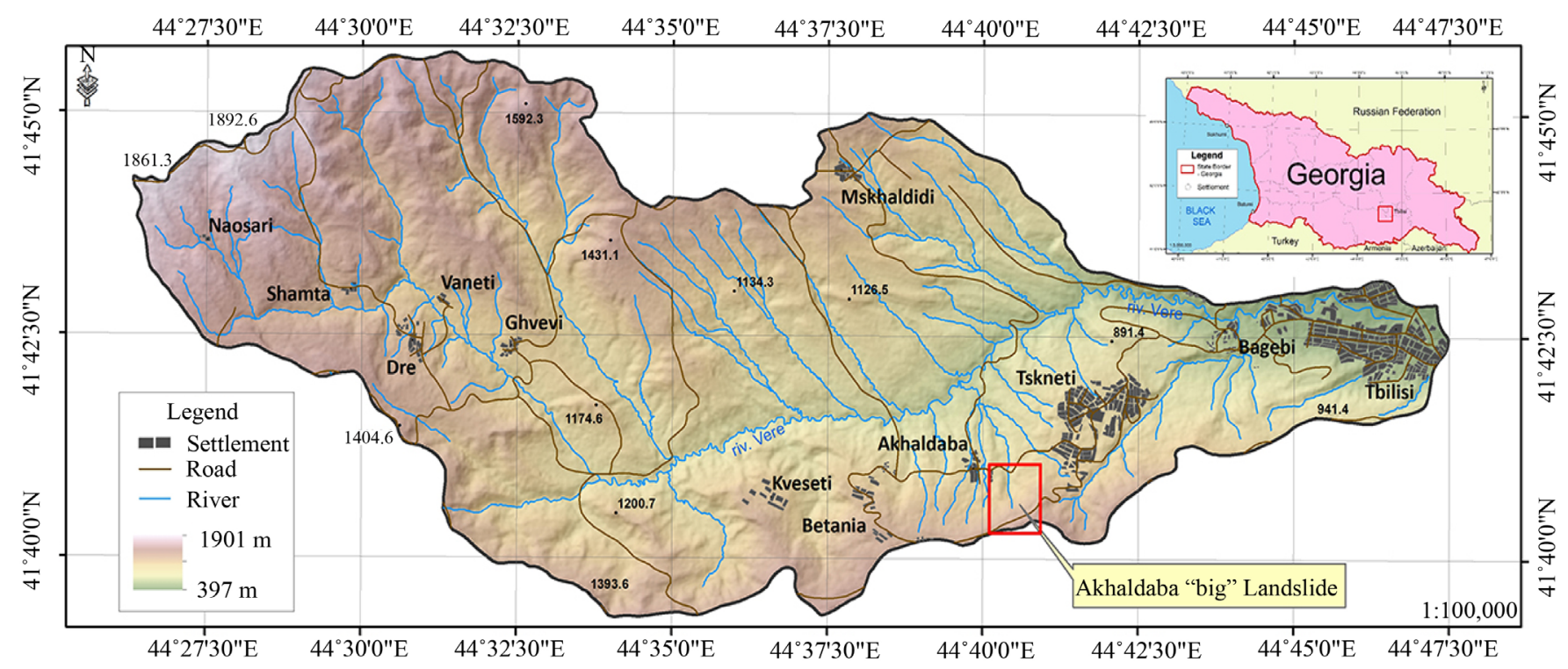

Figure 1. Study area (riv. Vere basin). 


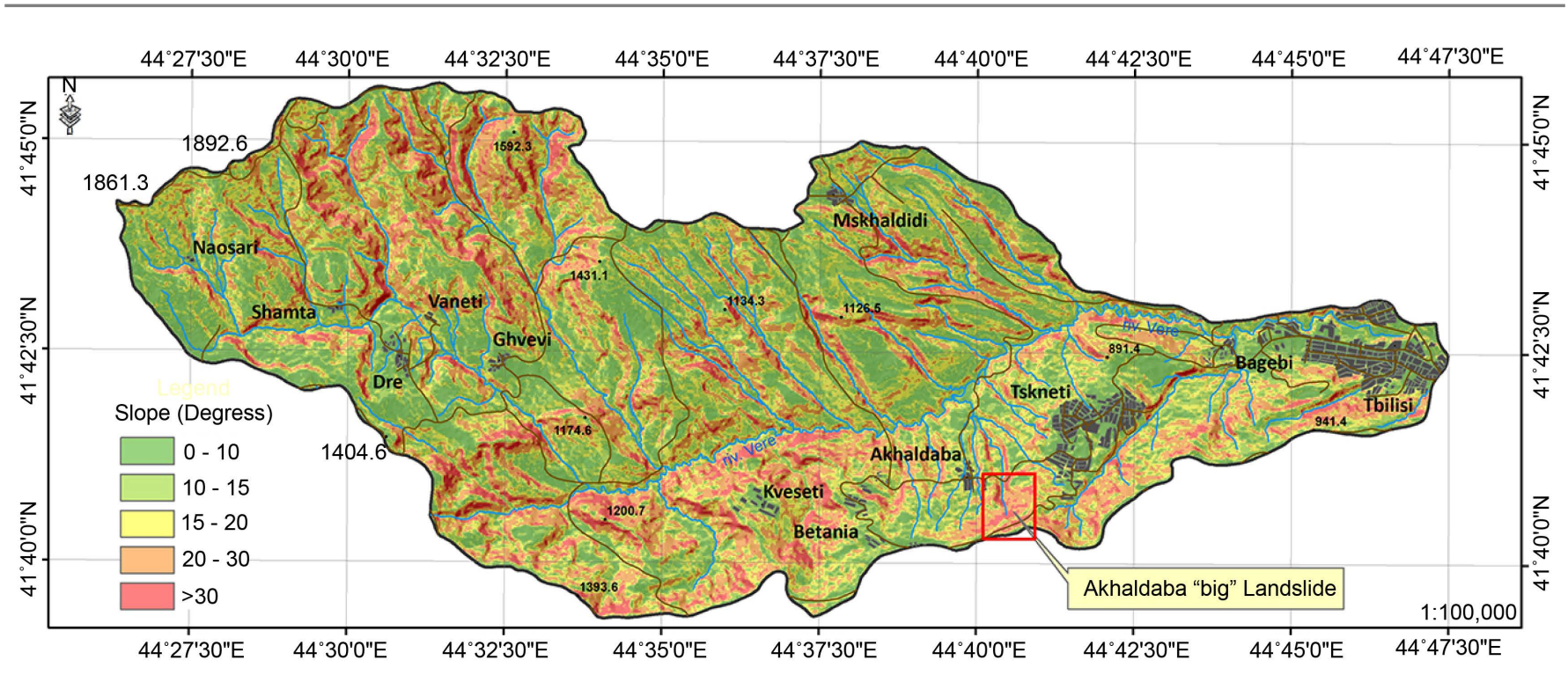

Figure 2. Slope map of riv. Vere basin.

layers of monoclinic structure rocks of slope. Therese morphological steps are currently in the state of stable condition and are anchored by the thick forests.

Under the current conditions for the morphological dynamics of the catchment basin of Riv. Vere and its tributaries, a strong asymmetric structure of the Gorge, developed in the monoclinic structure, is determining which is conditioned by the tectonic characteristics of its territory. With vigration of constituent rocks folding and tectonic fault of the layers, it is a main determining geological-morphological factor for developing gravitational-landslide and deep erosion processes. On the slopes of the gorges of the rivers, or on the slopes of the mountains, where the inclination of the layers coincide with the inclination of the surface of the relief gravitational-landslide processes dominate, and where the Rivers and gorges cross the areas directed opposite to the layers, strongly expressed deep erosive processes dominate.

\section{Geology, Tectonics and Hydrogeology}

Tectonics of the Tbilisi territory and specifically the catchment basin of the Riv. Vere is quite diverse. This is conditioned by its geological-geomorphological location between the geotechnical structures (Caucasus and Achara-Trialeti) of two strongly folded mountainous systems and within the area of the belt.

Basic rocks of the relief of the Riv. Vere catchment basin dating before Quaternary Period are represented with sedimentary rocks of Upper Eocene and Oligocene System [4]. The Oligocene Stratum is represented with carbonate, mainly with slated clays, which interchange with thin layers of sandstones (lower horizon) and thin-layered sandstones which interchange with clay and Alevrite packs (upper horizon). The capacity of the total Oligocene strata reaches up to 2000 meters.

Nummulite sets of flysch deposits are represented with thick-layer, coarse grain sandstone packs (often with coarse grain Grauwacke sandstones), which interchange with clay faciesAlevrolites, Argillites and slated clay interlayers. 
In engineering-geodynamic terms, the rocks described above are strongly dislocated with complicated tectonic faults. As a whole their strength and stability towards denudation-erosion and landslide-gravitational processes are low and instable though they are characterized with selective attitude towards these processes which is clearly expressed in development of geodynamic processes. This is why the slopes of the mountain and the slopes of the gorges are almost covered with young slope clay-loam and detritus facies the thickness of which range from a single meter to two tens of meters. Besides, alluvial-prolluvial and lacustrine sediments play a significant role within the territory, especially in piedmont and Tbilisi depression, which are especially sensitive towards landslide and erosion processes within the area of relevant relief.

According to the Hydrogeological Zoning of Georgia [5] the study area is located in Achara-Trialeti fold zone, Tbilisi water pressure system fracture and karst-fracture water hydrological district.

An anomalous increase of the ground waters as a result of excessive atmospheric precipitation played a key role in the catastrophic events that developed in the catchment basin of Riv. Vere on 13-14 June 2015 as well as the excessive saturation of the slope constituent basic rocks as well as the excessive saturation of Aluvial-Proluvial and Lacustrine clay-loam soils. In April-May-June there was big amount of precipitation (320 $\mathrm{mm})$, which is more than a half of annual precipitation (506 mm), most of them was saturated (especially in right slope of river) in the ground. On the study area during 2 - 3 days from the disaster excessive groundwater were discharged in the form of multiple frontal outcrops in the natural and artificial (including newly formed) exposures.

\section{The Statistics for the Prior Period Natural Disaster Processes in the Riv. Vere Basin}

Within the Greater Tbilisi, territory, among more than 60 rivers and gully drains identified on the territory, by activeness of debrisflow phenomena and hazardous risk, transformative debrisflows in the catchment basin of Riv. Vere draw a special attention because of its scale and hazardous risk. This is conditioned by a large area of the catchment basin, and the wing-like dissected relief with the frequency of dissection coefficient being $5 \mathrm{~km} / \mathrm{km}^{2}$ on average. Along with its high sensitivity of its constituent rocks to erosive and gravitational processes, their intensive folding, faults and complications in different directions and with interrupted dislocations are observed. In regard of adherence to the morphostructural conditions of the basin, denudation-erosive processes of the constituent rocks and peculiarity of the orientation of folds, 2 stages are distinguished in the geological development history of erosive forms-Lower Quaternary Period of the Riv. Vere Gorge, which is already at the maturation stage, and the gullies at modern active development stage which have not cut the substratum rocks yet [6].

Thus, considering the morpho-geological conditions, the vertical cutting depth of the relief in the catchment area of Riv. Vere ranges from 5 - 10 meters (in the form of completely young gullies) to 100 - 150 meters and by more in the second-third line rivers and it ranges within 400 - 500 meters for the water receiving main gorge of the Riv. 
Vere catchment area. Consequently, with these forms of various age and generation debrisflow profiling, formation of geological hearths takes place through different types of geological processes and in different quantity.

It is noteworthy that all the tributaries of Riv. Vere, separately or together, create a wide space catchment basin, which in case of prolonged rain and intensive snow melting, and after collecting surface runoff though the dependent water channels, -generate a significant amount of water flow in the main water channel (i.e. Vere Gorge). On top of it if the surface runoff regime changes, complicated with geological factors (landslide-gravitational processes) and free water saturates with solid inert materials, the natural reological nature of streams changes drastically and depending on the concentration of the geological components, it may become extreme, frequently ending with catastrophic outcomes. Besides, depending on the proportion of the participation of geological product under the conditions of the River flooding regime, we may be dealing with debrisflows with low-density debris or stone-muddy debrisflows of reological nature with high density. The debris flows that developed on 13-14 June 2015 were of this catastrophic type, which was formed because of the synergy of heavy rains and activation of landslide-erosive processes caused by negative meteorological events. Certainly, the one of the primary source for this catastrophe was heavy rain, which continued for several hours. Mountainous zone of the river there was precipitation more than $100 \mathrm{~mm}$. If we take into consideration the circumstance that according to the Tbilisi Meteorological Station only in April-May 2015 until 13 June 2015, the total precipitations exceeded the average multi-year precipitation by more than $60 \%$ it will be clear as to why landslide processes activated so strongly within the territory of Tbilisi. Moreover, on high inclination slopes, where a significant amount of the precipitation infiltrated in the soil, which was facilitated by thick forest on the right slopes of the mountain, followed by development of gravitational landslides in lithological sensitive and structurally facilitating constituent rocks on the, which were already in the upper limits of homeostatism.

If we analyze incomplete historical-statistical data on the flash floods and flooding in the Riv. Vere Gorge, which in most cases, when geological processes activate, transform into catastrophic debrisflows, it will be clear that such disasters have took place more than once during which the infrastructure of Tbilisi experienced a major loss and often human lives were lost. For example: at 8 pm on 12 June 1924, as a result of heavy rains, which continued for 1 hour, the debrisflow torrent swept away the pheasants settled temporarily with their bulls and carts into the Riv. Mtkvari (an article published in the newspaper Communist on 14 June 1924). On May 10 1940, flash floods and debrisflows occurred in all the Rivers and Gullies existing within the territory of Tbilisi. Specifically, flash floods and debrisflows occurred in the catchment basin of Riv. Vere brought along a large amount of sand and gravel in the territory of the City, which flooded yards, basements, streets, and the torrent flowing from the VarazhiKhevi swept away the University Street and the tram railway. On this day the precipitation of $109 \mathrm{~mm}$ was recorded. 
Catastrophic flooding and debrisflows of similar scale was observed on July 41960 when a significant part of the Zoo flooded and the water flow was registered at 259 $\mathrm{m}^{3} / \mathrm{sec}$. The loss was significant. According to some sources, flash floods and debrisflow took place in 1961 as well incurring a significant loss to the Zoo infrastructure and claiming lives of animals.

Flash floods and torrents also occurred in 1972 but catastrophic flash floods of debrisflow nature were recorded on 13 May 1980 when heavy rains broke through the gabion of the artificial water reservoir in Tskneti claiming lives of 8 persons, and destroying houses, killing a significant number of animals and incurring a huge loss to the infrastructure of the Zoo.

On 28 August 1999, flash floods occurred transmitting the flashflood of debrisflow nature in the City. Similar events took place on 15 October 2002 and the most recent catastrophes occurred in the catchment basin of Riv. Vere on 3 June and 13-14 June of 2015 , when the water discharge likely to be reached $470 \mathrm{~m}^{3} / \mathrm{sec}$.

\section{Reasons of June Disaster in the Year of 2015 and Its Negative Consequences}

As the statistical analysis show, a main triggering factor of flashfloods, debrisflows and landslide in the catchment basin of Riv. Vere is abundant atmospheric precipitations accompanied by high sensitivity of the geological environment and high energetic potential of the relief.

Multi-year geological observations and analyses show that in a relevant geological environment debrisflows are formed in case of precipitation $40-50 \mathrm{~mm}$ during 24 hours and the higher the intensity of heavy rains, these negative phenomena are more transforming into an extreme state.

The analysis of the statistical data shows that heavy rains above $50 \mathrm{~mm}$, that cause such extreme phenomena, occurred 52 times from to 1881 to 2014 (i.e. during 133 years) which indicate that the reoccurrence probability on average constitutes 0.4 per year. Besides, if during the years of 1960-1980 the reoccurrence probability of rains exceeding $50 \mathrm{~mm}$ during 24 hours was 5.41 years, in 1981-2000 the recurrence interval was 0.48 . Catastrophic debrisflow caused by gravitational landslides triggered on the right tributary of the catchment basin of Riv. Vere. The volume of the landslide amounted to 32 hectares and the height of the gravitational slide of the steep edge was 8 10 meters, with the total volume up to $1 \mathrm{mln} \mathrm{m}^{3}$, with an average width of the landslide of 350 meters. Its total length from the landslide release area up to the riverbed of riv. Vere, amounted to $3.8 \mathrm{~km}$. Besides this Akhaldababig landslide, there were more than 100 different scale landslide conception and activation [7].

In our case, we do not have typical landslide events when it is brought into dynamics by increased "moisture effect" bringing down moving rocks to sliding consistency. In case of such a landslide, the inclination of the layers and that of the relief surface coincide, at where the interchange of slated clays with sandstones starts. They start gravitational movement in the first section under the block-crawl regime covering at around 
300 meters where along with the movement significant quantity of sandstone blocks and fractured rocks remain on the slope (Figure 3). Further, up to Village Akhaldaba at approximately 700 meters it transfers into liquid-soft state below the village road where it appears in quite a deeply down cut gully of Jokhani Tskali. After appearing in the riverbed with a significant inclination, it transforms into a typical debrisflow movement regime, the rocks-muddy stone material hits with great energy on the bed of the Riv. Vere Gorge and congests it with short intervals increasing the level of Riv. Vere up to 3 4 meters, though it did not play a significant role in increasing the total flow. The flow leaves behind the rocks (Figure 4) and continues flowing in the Vere Gorge, mostly saturated with fine-grained fraction, which brings along the wooden materials brought down from the body of the landslide. This mix of water-mud-stones along with a large amount of the vegetation got down on the territory of the City. We consider that it was the vegetation mixed with the muddy mass which became a key reason of blocking the tunnels in the riverbed and leading to overflowing in the outer space of the riverbed, which caused such a big tragedy in the City claiming the lives of up to 20 persons, de-

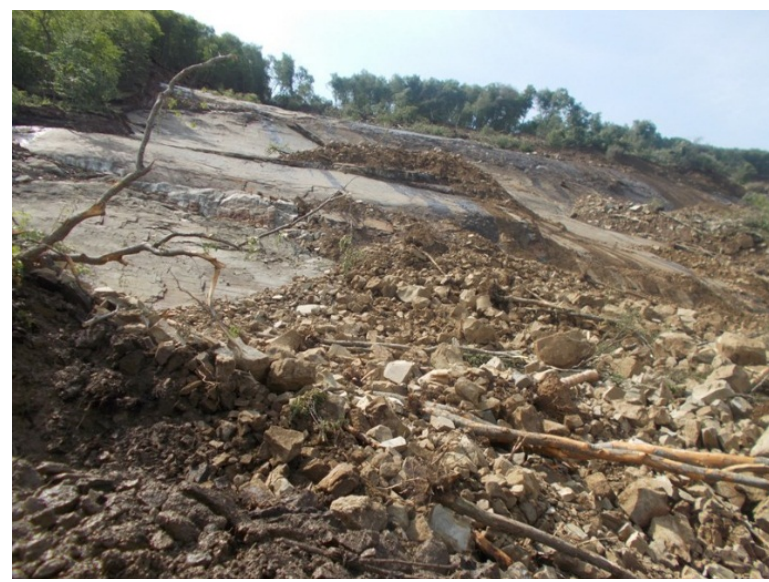

Figure 3. Sandstone blocks and fractured rocks remain on the slope.

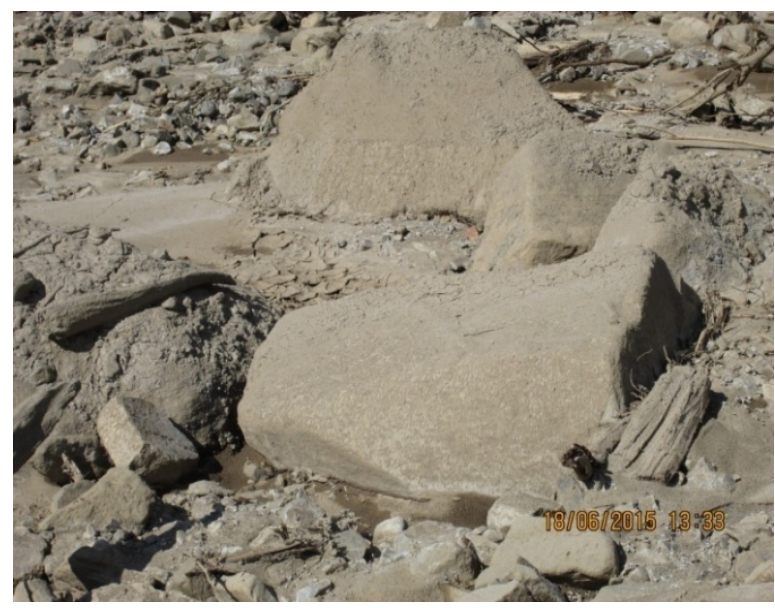

Figure 4. Jokhani-Khevi debrisflow material near riv. Vere. 
stroying a significant part of the Zoo along with the animals and damaging a number of residential houses and buildings, roads and other infrastructure. The total loss exceeded $50 \mathrm{mln}$ USD [7].

\section{Geodynamic Situation of Akhaldaba Big Landslide Developed at the Tskneti-Samadlo Road Section}

The Akhaldaba big landslide is developed on $40^{\circ}-50^{\circ}$ inclination slope with the NorthNorth/West exposition starting from its crescent and spreading up to environs of Village Akhaldaba (Figure 5 and Figure 6).

The landslide is of elliptical shape in the plan with small landslide activations adjacent to it. Its upper part is located in the crest part at 1415 - 1420 meters of absolute

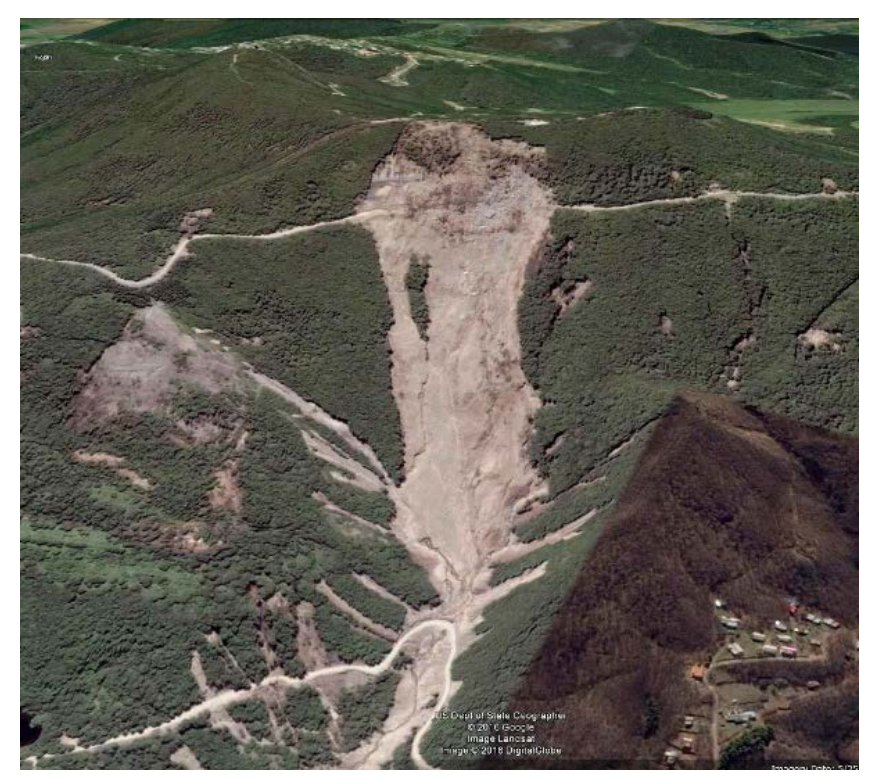

Figure 5. Akhaldaba "big" landslide [8].

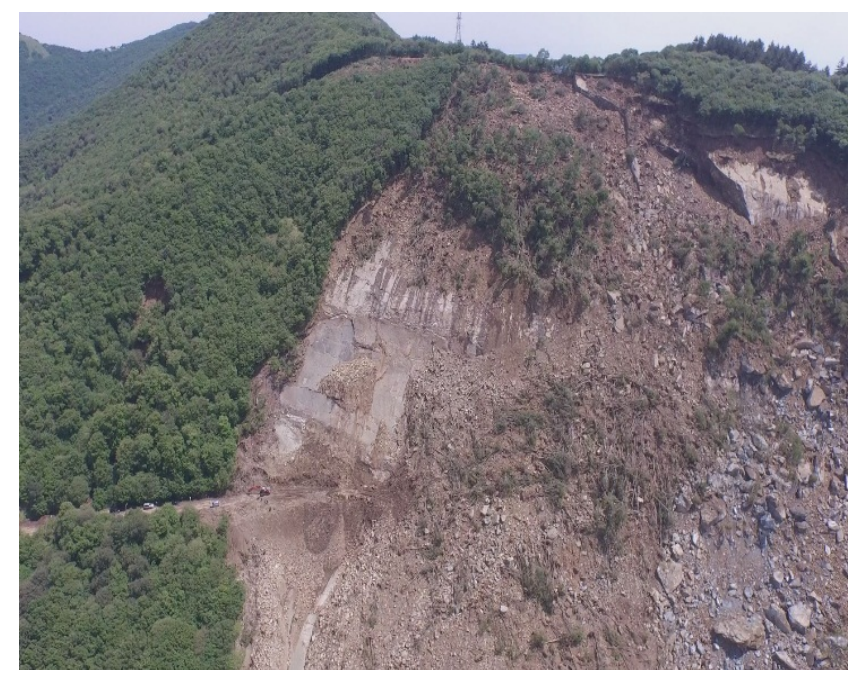

Figure 6. Akhaldaba "big" landslide. 
elevations, while the basis is the territory adjacent to the motor road of Akhaldaba-Tskneti at 1250 - 1280 meters within the absolute elevations. The difference in height between them is 150 - 180 meters with the length of $1 \mathrm{~km}$ while the average width of the landslide body is 350 meters. Visually the capacity of the landslide, following its slide layers and outcrops, constitutes 3 - 4 meters at the East wing and at the West wing; it ranges from 2 - 3 meters to 6 - 8 meters.

Adjacent to the East wing of the landslide there are three landslide fractures of EastWest direction developed with the length of 20 - 30 meters, and the width of it is from 0.5 to 1.0 meters and with the visual depth from 0.2 to $1-1.5$ meters (Figure 7 and Figure 8).

Adjacent to the West of the landslide there are two landslide raptures developed. One of them is located at the crest, at $100-150$ meters from the military road and with the length of 100 meters and with the width of $0.2-0.4$ meters (Figure 9). In addition, the other one is at 1274 meters absolute elevation, below the motor road, and of a semicircle shape, with the width up to 0.5 meters, and the visual depth is from 0.5 - to 1.0

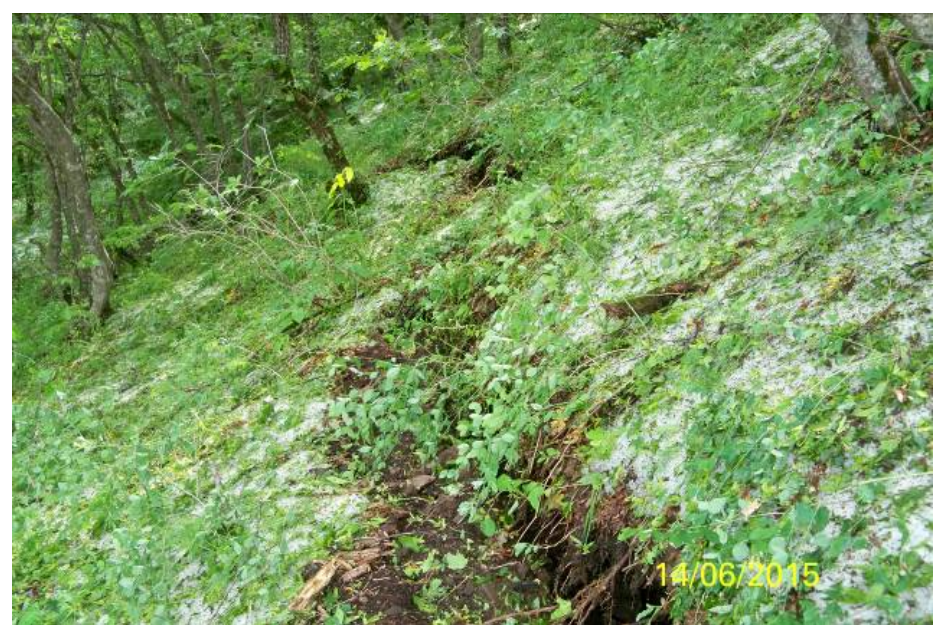

Figure 7. Fractures on Akhaldaba big landslide.

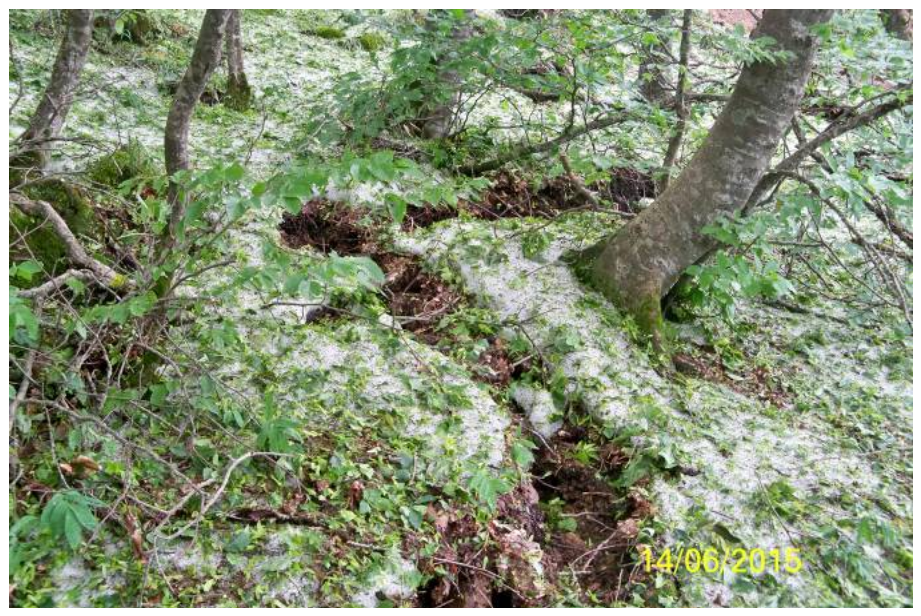

Figure 8. Fractures on Akhaldaba big landslide. 
meters (Figure 10).

Further regressive development of the landslide body is excluded at this stage, while its width will presumably increase (considering the adjacent fractures) by $150-200$ meters. Its progressive development is also presumable.

The landslide steps are not observed since the landslide is represented by mirror wavy surface of the rocky layers (Figure 11) on which detritus is accumulated in which several stepped accumulation can be identified, especially in the upper part of the landslide body. Detritus are represented with various size broken rocks and boulders (from 5 - 6 to 10 - 12 meters) (Figure 12).

According to the movement mechanism the landslide is divided in three parts: the upper part from the crescent to the motor road of Tskneti-Samadlo is of block-sliding

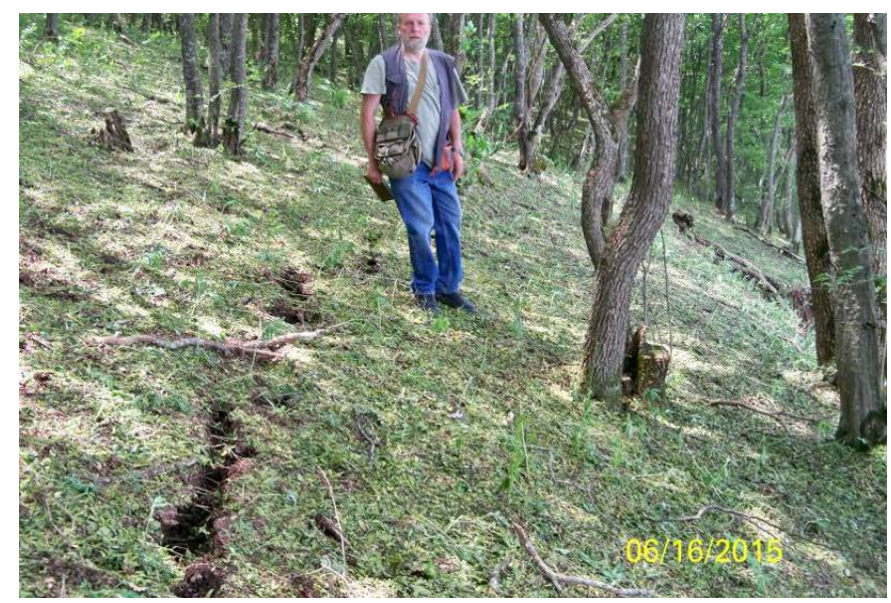

Figure 9. Fractures on Akhaladaba big landslide.

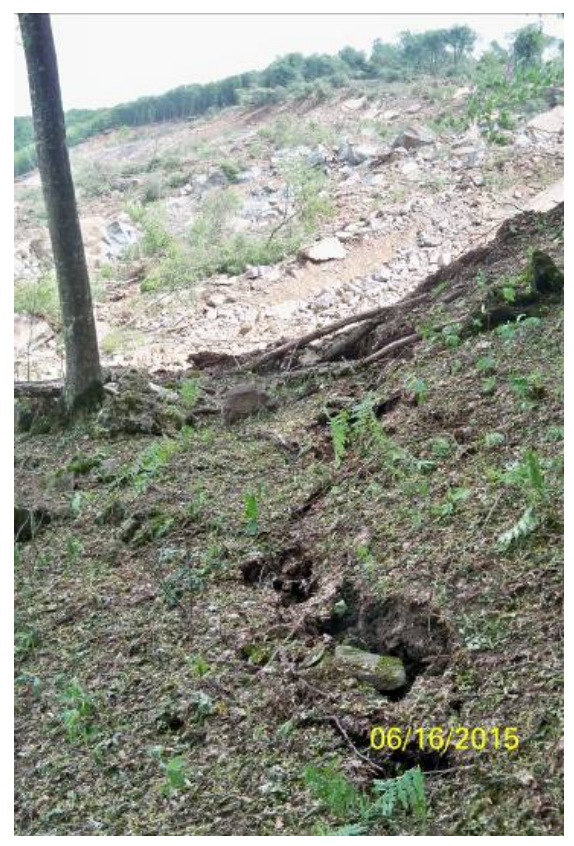

Figure 10. Fractures on Akhaladaba big landslide. 


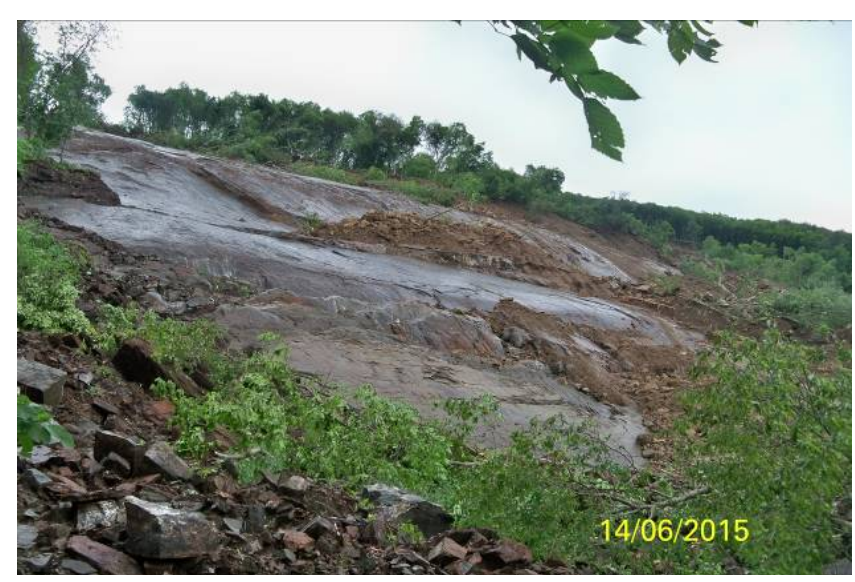

Figure 11. Mirror wavy surface of the rocky layers.

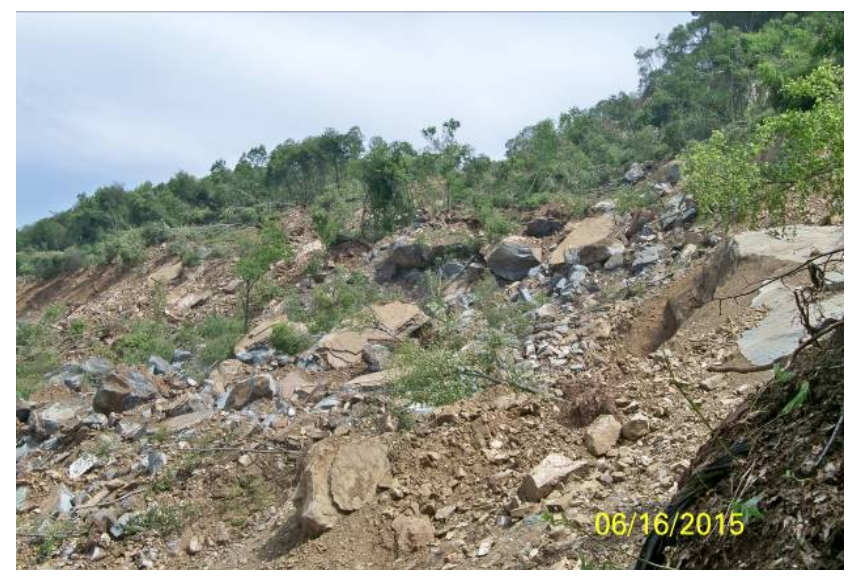

Figure 12. Various size broken rocks and boulders.

type, further up to the Village Akhaldaba it transforms into liquid-soft section (with the width of $70-100 \mathrm{~m}$ ) and in the last section up to the Riv. Vere it transforms and acquires a debrisflow nature (Riv. Jokhani Gully). The total length of the landslide development from the crescent up to the Riv. Vere is $3.8 \mathrm{~km} \mathrm{[6]} \mathrm{(Figure} \mathrm{13).}$

The debrisflow temporarily (for $1-2$ minutes) congested Riv. Vere though no classic congestion and its breaking through were not observed and consequently, the discharge of Riv. Vere did not increase significantly. At the merging site diameters of certain rocks reaches 1.5 - 2.0 meters (Figure 14)

The landslide process is geologically developed in the upper Eocene set represented with thick and massive sandstones and clay interlayers, which are overlaid by 0.5 2.0-meter thickness (and at some places even more) delluvial clay sediments, covered with the forest vegetation.

The landslide area affected three motor roads: 1) First road-the road in the crest part of the landslide, the local ground road (for energy specialists) which is torn off at several tens of meters length and also the high voltage transmission tower adjacent to it also slid; 2) Second road-the motor road connecting Tskneti-Samadlo, is torn off at meters 350 length (Figure 15); 3) Third road-the motor road with asphalt pavement, that 


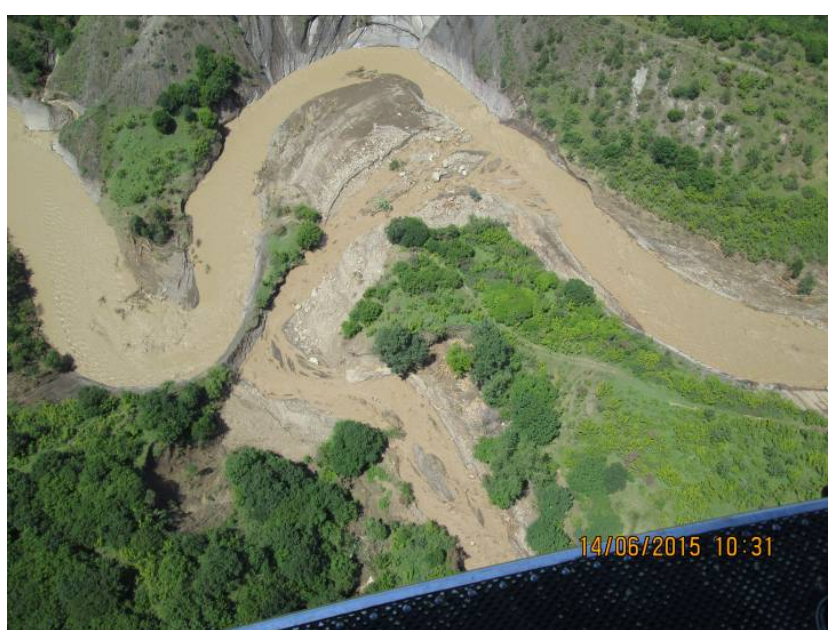

Figure 13. Connection of riv. Jokhanikhevi and riv. Vere.

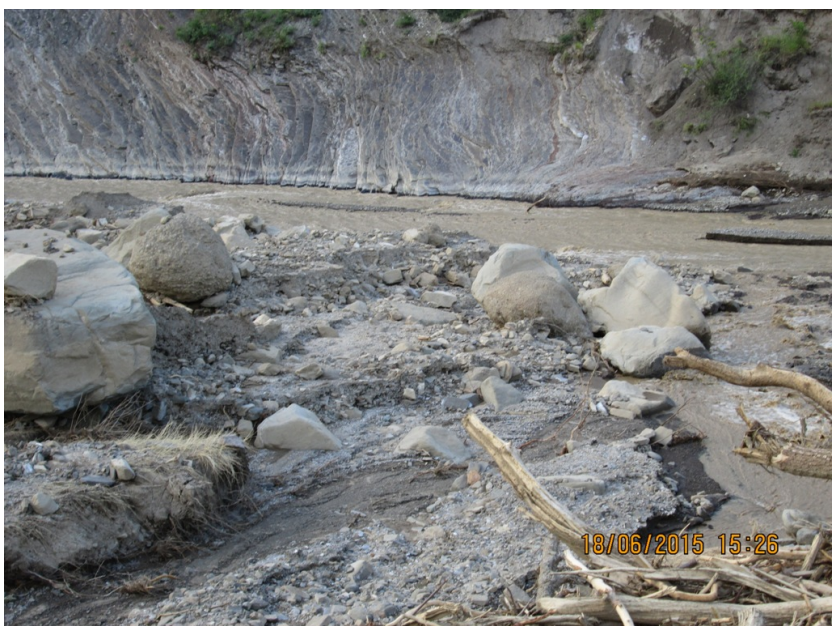

Figure 14. Debrisflow material of Jokhani-khevi alluvial fan.

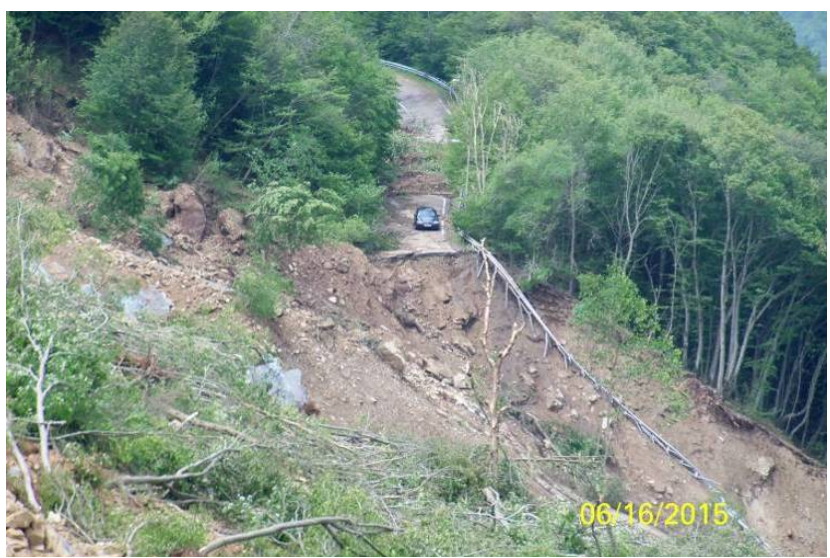

Figure 15. Destroyed Tskneti-Samadlo road.

connects Tskneti-Akhaldaba, is damaged and overlaid by landslide broken rock-clay materials (Figure 16). 


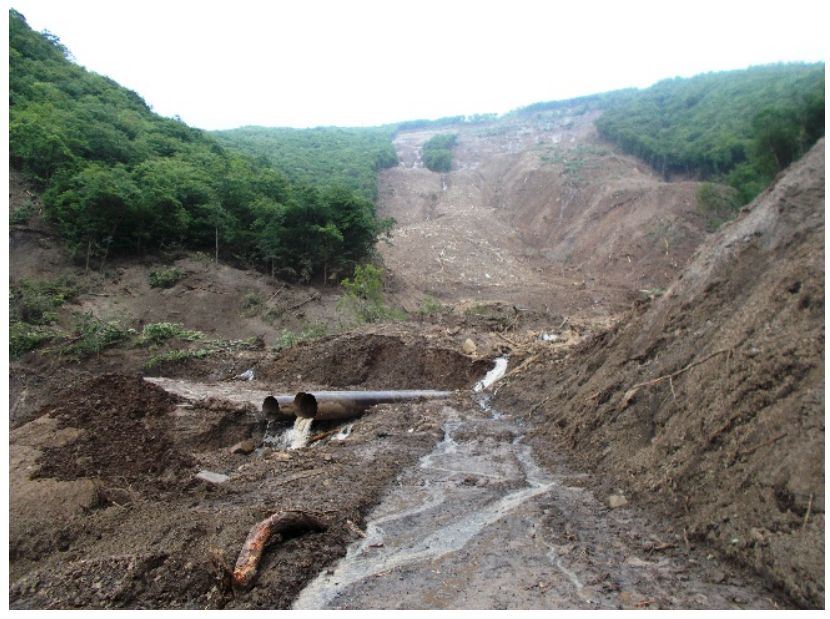

Figure 16. Destroyed Tskneti-Akhaldaba road.

\section{Conclusions and Recommendations}

The catastrophic event that developed in the catchment area of Riv. Vere on 13-14 June 2015 was triggered by the coincidence of geological and hydro-meteorologi- cal events, specifically: landslides, debrisflow/mudflows, rock-avalanche/rockfall, precipitation in the form of rain and hail, lateral and deep erosion of the existing water channels, flash floods and flooding. The main triggering factor occurrence of Landslide-Gravitational and Debrsiflow events is complex morphological, geological, hydrogeological and tectonic conditions of the Riv. Vere catchment basin. While studying the area, a sub-meridian orientation fault (from the North-East to South-West) is observed, which spreads from the Mama Daviti anticlines towards Village Kiketi and runs along the crest of the watershed of Tskneti and Kojori. It was in this area that the release of Akhaldaba big landslide body was observed. Besides, various types of engineering works starting from 1930s up to present in the Riv. Vere floodplain and riverbed zone increased the damage and harm of the disaster within the City area. Among engineering works are: residential houses, car garages, construction of roads and other types of infrastructural facilities;

Prolonged and heavy rains significantly contributed to the development of the disaster (during the recent 2.5 months the rainfall exceeded the multi-year average by $60 \%)$. A significant amount of water was infiltrated into the rocks, influenced by the thick forest on the territory, and eventually led to development of a large scale landslide-gravitational process which was transformed into debris flows.

The tunnels in the city failed to fully and timely pass muddy flows since they were blocked mostly by the forest cover removed by the landslides from the slopes on the Gorge transferring them in the main artery (Riv. Vere). Only on the area of so called "Big Landslide" and on its adjacent territory the processes swept away more than 4000 cubic meter tree and shrub species;

The catastrophic events put the towers of high-voltage lines, gas pipelines, motorroads, water channels, storm collectors out of order and destroyed residential hous- 
es and supporting facilities, and killed some of the zoo population (a significant number of animals killed), and the most regretful is the claimed lives of 23 people;

Considering the properties of the Riv. Vere, which are well confirmed by the historic facts, similar cataclysms are expected to repeat more than once in the future. For the future mitigation processes, it is necessary to take some protective measures, such as the installation of early warning systems, construction of flow containment structures in the flood plain-river bed zone, regulation of the riverbed within the city and so on.

\section{Acknowledgements}

The authors would like to thank National Environmental Agency of Ministry of Environment and Natural Resources Protection of Georgia for providing various datasets used in this study.

\section{References}

[1] Information Bulletin (2000) Underground Hydrosphere Ecological Conditions and Disaster Geological Processes and Prediction. Georgia State Department of Geology, Tbilisi, 410 p.

[2] Informational Bulletin (2013) Condition of Development of Geological Processes in Georgia, Results of Activation in 2012 and Danger of Risk by 2013 Summarizing Geological Report. Tbilisi.

[3] Gobejishvili, R. (2011) Relief of Georgia. Ivane Javakhishvili Tbilisi State University, “Uni-versal”, Tbilisi.

[4] Buachidze, I. (1970) Hydrogeology Zoning Map of Georgia. TSU, Tbilisi, 203 p.

[5] Buachidze, I. (1970) Hydrogeology Zoning Map of Georgia. Tbilisi.

[6] Informational Bulletin (2016) Condition of Development of Geological Processes in Georgia, Results of Activation in 2015 and Danger of Risk by 2016 Summarizing Geological Report. Tbilisi.

[7] NEA (2015) General Analysis of Threats of Natural Disasters on the Territory of Tbilisi and Preliminary Assessment of the Situation Created after the Disaster that Developed in riv. Vere Catchment Area on 13-14 June 2015. Tbilisi.

[8] (2015) Google Earth V 7.1.5.1557. Akhaldaba, Tbilisi, 203 p. 
Submit or recommend next manuscript to SCIRP and we will provide best service for you:

Accepting pre-submission inquiries through Email, Facebook, LinkedIn, Twitter, etc. A wide selection of journals (inclusive of 9 subjects, more than 200 journals)

Providing 24-hour high-quality service

User-friendly online submission system

Fair and swift peer-review system

Efficient typesetting and proofreading procedure

Display of the result of downloads and visits, as well as the number of cited articles

Maximum dissemination of your research work

Submit your manuscript at: http://papersubmission.scirp.org/ 